\title{
Does Green Credit Affect the Green Innovation Performance of High-Polluting and Energy-Intensive Enterprises? Evidence from A Quasi-Natural Experiment
}

\section{Sheng Liu}

Guangdong University of Foreign Studies

RONGXIN XU ( $\nabla$ xu.rongxin@connect.um.edu.mo)

University of Macau https://orcid.org/0000-0002-9213-3462

\section{Xiuying Chen}

Guangdong University of Finance

\section{Research Article}

Keywords: green credit, green innovation, DID, PSM

Posted Date: March 9th, 2021

DOl: https://doi.org/10.21203/rs.3.rs-205842/v1

License: (c) (i) This work is licensed under a Creative Commons Attribution 4.0 International License.

Read Full License

Version of Record: A version of this preprint was published at Environmental Science and Pollution Research on July 6th, 2021. See the published version at https://doi.org/10.1007/s11356-021-15217-2. 


\section{Does Green Credit Affect the Green Innovation Performance of High-polluting and Energy-intensive Enterprises? Evidence from a Quasi-natural Experiment}

Abstracts: Green credit policy is a practical exploration to guide green development through the allocation of financial resources, but there is a gap in the theoretical research on how green financial policy affects enterprise green technology innovation. Taking the green credit policy in 2012 as a quasi-natural experiment, this paper applies the methods of Propensity Score Matching and Difference in Difference (PSM-DID) to investigate the relationship between green credit policy and enterprises' green technology innovation behavior based on Chinese industrial enterprises database and green patent database. The results show that the implementation of "green credit guidelines" policy has significantly improved the green innovation output of high-polluting and high-energy consuming enterprises, which indicates that the incentive effect of green credit policy on enterprises exceeds the inhibition effect and leads to Porter effect. Moreover, the green credit policy has significantly increased the number of non-invention patents rather than invention patents. In addition, the green credit policy has a more significant effect on the innovation output of heavily polluting enterprises in state-owned and weak market power enterprises. Mechanism test shows that green credit policy mainly affects the green innovation output of heavy polluting enterprises by guiding the loan financing cost and R\&D investment allocation.

Keywords: green credit, green innovation, DID, PSM

\section{Introduction}

More and more countries regard green innovation as a key to solve the current global environmental problems. Hence, theoretical research on the driving factors of enterprises' green technological innovation behavior and how to break through the bottleneck of green innovation to stimulate the full potential of enterprises' green upgrading has become the top priority. Most early studies on enterprise's innovation have not separated the green patents from the general kinds of patents, which suggests that Schumpeter's theory of innovation and other traditional innovation theories can also apply to the green technology innovation area. Thus, the green innovation behavior has long been considered to be driven by technological progress, market demand and other market factors according to previous research (Foster et al., 2000; Magnusson, 2003). However, subsequent studies show that environmental regulation factors, especially a series of green financial policies that can decide credit funds allocation according to environmental risk of clients, also have a non-negligible impact on enterprises' green innovation behavior (Horbach, 2008; Li et al., 2018). Therefore, developing a policy system of green credit to stimulate the green transformation of high-polluting and energy-intensive enterprises is regarded as a key environmental regulation tool to alleviate the credit risk of such specific enterprises and solve the existing severe pollution problems.

China is one of the important countries committed to promoting the development 
of green technology innovation, so the actual effect of its green credit policy can make substantial contributions to global sustainable development. In view of the lagging development of the financial system in transitional countries, the huge potential of green financial policies has yet to be released. Unlike enterprises in developed economies that can easily obtain credit funds from multi-level capital markets, most enterprises, especially SMEs in transition economies, mainly obtain their credit funds from the banking system through strict approval procedures and high qualification requirements. Under the supervision and management of the China Banking Regulatory Commission(CBRC), the environmental risk prevention in the credit business of commercial banks affected by policies which are formulated by regulatory agencies, and it may substantially impact enterprises' credit behavior (Liu et al., 2017). To better guide the green innovation behavior of enterprises, the "Green Credit Guidelines" policy was promulgated by the China Banking Regulatory Commission in 2012. After several years of implementing this policy, we want to know whether this green credit policy can effectively promote green technology innovation and transformation of high-polluting and energy-intensive enterprises. If the green credit policy is effective, what channel or mechanism does it apply to influence enterprises' green technological innovation activities? Solving these problems has important practical implications for accelerating green credit and sustainable development in many developing countries. To achieve these research objectives, this paper takes the promulgation and implementation of China' s "Green Credit Guidelines" policy as an exogenous shock. Based on this Quasi-natural experiment, we explore the effect and its impact mechanism of green credit policies on the green innovation behavior of high polluting and energy-intensive enterprises.

Nowadays, there is still no consensus yet on the impact of green credit policy on enterprises' green innovation performance so far. On one hand, some references revealed that green credit policy might aggravate high-polluting and energy-intensive enterprises' financing constraints and thus reduces their innovation investment. In the neoclassical economics theory, strict environmental regulations are more likely to show negative effects on enterprises' innovation activities since they raise the threshold of investment access and the cost of pollution control (Gray et al., 1995; Jaffe, 2004). Due to the punitive interest rate and credit threshold imposed by green credit policies on the financing activities for related industries, the total amounts of financing and investment of those industries are significantly controlled or reduced (Liu et al. , 2017). In view of this, green credit policies can demonstrate asymmetric effects on environmentally-friendly enterprises and high-polluting and energy-extensive enterprises. More specifically, the green credit policies may reduce the former's financing costs, but conversely increase the latter's financing costs and shorten their financing maturity(Liu et al., 2019; Xu et al., 2020). Furthermore, some studies show that financing constraints are the main obstacles to enterprises' innovation especially green innovation activities. Compared with the general kinds of innovation, the dual externalities of green innovation intensifies the financing constraints of enterprises. In addition to the traditional spillover effects of R\&D, 
green innovation also generates environmental benefits due to improved using efficiency of resources and reduced resource consumption. If the market price of an enterprise's environmentally friendly products and services are not enough to reflect the externalities of green technology innovation, in other words, if the economic benefits of the enterprise are lower than its green innovation costs, it will reduce the enterprise's enthusiasm for investing in green innovation and bearing higher cost pressures than its competitors, which further aggravates the financing constraints of the enterprise (Kapoor et al., 2011). Therefore, the overall capital strength of an enterprise largely determines the investment level of its green innovation. When the enterprises' financing constraints become more aggravated, they are likely to reduce the R\&D investment in green innovation (Demirel et al., 2015; Cecere et al., 2020). From this perspective, the green credit policy may reduce the financing sources of high-polluting and energy-extensive enterprises and restrict capital investment for their green innovation activities.

On the other hand, some studies argue that green credit policy shows an incentive effect on the green innovation of high-polluting and energy-intensive enterprises. According to the Porter Hypothesis, appropriate environmental regulation policies can induce high-polluting and energy-intensive enterprises to adopt energy-saving and emission reduction technologies. The cost savings by using green technology innovation can overcompensate the innovation costs and make their production processes and final products more competitive (Porter et al., 1995a, 1995b). Many subsequent studies have affirmed the hypothesis. For example, Kesidou et al. (2012) explored the driving factors of ecological innovation through quantile regression based on panel data of British enterprises, and concluded that environmental regulations trigger the ecological innovation of enterprises. Further, manufacturers can also obtain preferential policy benefits by introducing clean technologies, create more added values and free up more R\&D funds to further support green innovation activities (Kang et al., 2020). Figure 1 is a brief summary of the related existing literature.

Based on the existing research, this article tries to carry out the following marginal expansions. For the research perspective and content, the existing literature discusses the green credit policy effects or the influencing factors of enterprises' green innovation behavior respectively, but few can bring them into the same analytical framework and explore their relationship systematically. Specifically, some papers focused on the financing constraints and R\&D investment and other influencing factors on green innovation of enterprises, but few studies link the green credit policies and enterprises' green innovation together to discuss the green credit policy's impact and its mechanism comprehensively. Some other researches analyzed the impact of green credit policies on the enterprises' productivity, financing, investment and other activities, while studies of the effect of green credit policy on green innovation from an event-shock perspective are insufficient. Though a few articles discuss the relationship of green credit policy and general patent innovation, they have not separated the green patent innovation from the general patent innovation, and have not emphasized the 
particularity of green patent technology embedded with environmental factors. Therefore, it is not conducive to highlight the precise implementation object of green credit policy, nor give full play to the dual externalities of green patent technology. Second, for the logic of discussion, most research merely considers the constraint or incentive effect of green credit policies, but rarely combines the dual effects into the same analytical framework to make an overall evaluation. Therefore, the conclusions may be biased since these two effects of green credit policy on enterprises' green innovation exist simultaneously. Third, for research methods and data, some previous studies on environmental regulation and enterprise's innovation mainly used the static panel regression models or regional data to conduct empirical analysis, but such a "Single-Difference-Analysis" empirical method and macro-level data analysis may cause endogenous problems and come to biased estimation results.

Given the previous shortcomings, this article tries to consider both the constrained and incentive effect of green credit policies on the enterprises' green innovation behavior from the perspective of enterprise's heterogeneity, and implements a Quasi-natural experiment method to overcome the potential endogenous problem. To ensure that the research sample meets the randomness and homogeneity requirements, this paper further uses the method of propensity score matching (PSM) to match Chinese listed enterprises. Then, the Difference-in-Difference (DID) method is applied to explore how the "Green Credit Guidelines" policy affects the green innovation behavior of high-polluting and energy-intensive enterprises.

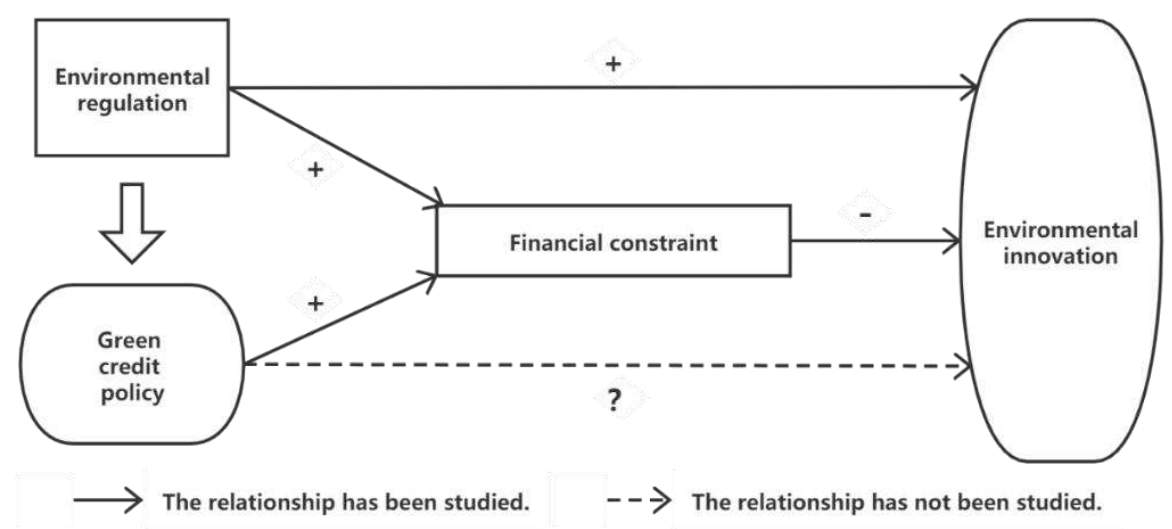

Fig. 1.The logical relationship between the key variables

The rest of this paper is organized as follows. Section 2 provides a theoretical framework of the relationship between the "Green Credit Guidelines" policy and enterprises' green innovation behavior and proposes research hypotheses. Section 3 introduces empirical models and explains the data source. Section 4 reports empirical results, which include robustness testing and heterogeneity analysis, and section 5 concludes.

\section{Theoretical framework and research hypothesis}

\section{1 Policy background}

In July 2007, China's State Environmental Protection Administration (SEPA), the 
People's Bank of China (PBOC), and the China Banking Regulatory Commission (CBRC) jointly issued the "Opinions on the Implementation of Environmental Protection Policies and Regulations to Prevent Credit Risks", marking green credit as a policy tool for environmental protection and emission reduction in China. However, this document does not formulate specific implementation measures on how to carry out green credit policies. Subsequently, in February 2012, the CBRC issued the "Green Credit Guidelines" (CBRC [2012] No. 4) as the new core of China's green credit policy system. It provides feasible guidance for financial institutions, mainly commercial banks, on how to carry out green credit policy and promote the green transformation of the related industries. This policy is likely to influence the financing costs, financing scale, and financing maturity of enterprises especially those with high pollution and high energy consumption, and further affect their green innovation behavior.

The rules of "Green Credit Guidelines" can be summarized into three aspects. First, commercial banks should set more strict conditions for access to financing, embed environmental factors into the risk management system of credit business, and refuse to grant loans to enterprises with poor environmental performance. Second, the policy guides financial institutions to allocate more credit funds to environment-friendly enterprises. Commercial banks are encouraged to reduce credit scale or charge a punitively high interest rate for high-polluting and energy-intensive enterprises, while in contrast increasing financial support for environment-friendly enterprises. Third, financial institutions should dramatically strengthen their management ability of environmental risks. After issuing the loans, commercial banks need to scrutinize the use of credit funds strictly to ensure that credit funds flow in green innovation activities and achieve better eco-economic benefits.

\section{2 Mechanism analysis and Research hypotheses}

The guiding role of green credit policy on green innovation behavior of enterprises is achieved more through market incentives than administrative instructions, aiming to differentiate credit resource allocation among various enterprises through market signals. This policy actively provides credit support to environmental-friendly enterprises, while restricting credit support to high-polluting and energy-intensive enterprises. On this basis, this policy can affect the financing resource allocation structure and green innovation behavior of specific enterprises. Further, it is noteworthy that the green credit policy may show incentive and constrained dual effects on the green innovation performance of high-polluting and energy-intensive enterprises.

\subsubsection{The constraint effect of the "Green Credit Guidelines"}

Under the "Green Credit Guidelines" policy, commercial banks are guided to prioritize credit access to environment-friendly enterprises, while restricting the credit supply of high-polluting and energy-intensive enterprises. From this perspective, the financing sources and innovation investment of the high-polluting and energy-intensive enterprises could be constrained if they cannot effectively achieve the green transformation. 
After implementing the "Green Credit Guidelines" policy, commercial banks no longer merely focus on enterprises' economic profit status, but instead the role of environmental performance is more prominent in the credit process. Also, the commercial banks are induced to raise the threshold of credit access and increase the interest rate of loansfor high-polluting and energy-intensive enterprises. Under such circumstances, these types of enterprises may have to reduce financing scale due to higher financing requirements and financing costs (Lemmon, 2010; Liu et al., 2019). Besides, the "Green Credit Guidelines" policy stipulates that creditors may be exposed to environmental litigation if serious environmental problems happen during the credit business. Therefore, financial institutions are less willing to provide debt capital to high-polluting and energy-intensive enterprises since the environmental risk of such credit business is usually high. Furthermore, green innovation is characterized by high investment risks and usually very long payback periods. Enterprises normally prioritize investing in routine business activities or even temporarily stop R\&D activity on green and energy-efficient technologies when facing a serious shortage of funds (Aghion et a1., 2012). Thus, credit constraints are likely to limit enterprises' R\&D investment for green innovation activities (Ghisetti et al., 2017). In summary, from the perspective of financial constraint, the "Green Credit Guidelines" policy aggravates the financing constraints of high-polluting and energy-intensive enterprises, which probably would reduce the R\&D funds and inhibit the green innovation performance of specific enterprises.

\subsubsection{The incentive effect of the "Green Credit Guidelines"}

As a green financial tool, the "Green Credit Guidelines" policy does not aim to directly intervene in the daily production or business management activities of high-polluting and energy-intensive enterprises, but would send negative signals to stimulate these enterprises' green upgrading progress through differentiated credit strategies (Wang et al., 2019).

As China's environmental regulatory and supervisory system is not mature enough, the attitudes and behaviors towards green innovation transformation of managers in high-polluting and energy-intensive enterprises are different. Before the promulgation of the "Green Credit Guidelines" policy, high-polluting and energy-intensive enterprises are facing greater environmental pressure. The increase in environmental protection expenditure will increase the production cost of enterprises. Therefore, some enterprises tend to retain backward production equipment and technology, and lower emission standards to reduce production costs and gain the market competitive advantage. And, the financial situation is a primary reference factor in the traditional credit business. Thus, those enterprises with good profit performance are more likely to receive credit support, which in turn incentivizes them to reduce production costs by taking the environment as a price. In this circumstance, environmental-friendly enterprises are in a disadvantageous position and face the threat of being replaced by the high-polluting and energy-intensive enterprises, which seriously hinders the green transformation and sustainable development of related industries. 
In light of this, the "Green Credit Guidelines" policy requires commercial banks to implement classified management of various enterprises, giving priority to credit cooperation with enterprises with good environmental performance, while refraining from providing credit support or imposing punitive interest rates on enterprises with high environmental risk, thereby internalizing enterprises' external environmental costs. Since the implementation of the "Green Credit Guidelines" policy, commercial banks further develop the environmental risk management systems and improve credit policies in such processes as granting credit, qualification examination and post-credit supervision. Thus, commercial banks can identify environmental risks in the credit business more accurately. Driven by such differentiated credit policies, high-polluting and energy-intensive enterprises have incentives to change their business strategies. Enterprises with poor environmental performance are more likely to actively develop green technology innovation to reduce pollution and energy consumption so as to obtain credit funds and reduce credit costs (Tsai et al., 2017; Zhang et al., 2020). Moreover, labels such as "environmentally friendly" and "energy-saving" are helpful for enterprises to build brand image and social reputation (Hou et al., 2019).

Therefore, the "Green Credit Guidelines" shows both constraint and incentive dual effects on the green innovation performance of high-polluting and energy-consuming enterprises, but whether the net effect is positive or negative remains to be explored through empirical analysis. Thus, this paper proposes the following research hypotheses.

H1: The "Green Credit Guidelines" policy has a significant impact on the green innovation behavior of high-polluting and energy-intensive enterprises.

H2: The "Green Credit Guidelines" policy is likely to increase financing constraints of high-polluting and energy-intensive enterprises and restrains their green innovation activities.

H3: The "Green Credit Guidelines" policy is likely to strengthen R\&D incentives of high-polluting and energy-intensive enterprises and promotes their green innovation activities.

\section{Methodology}

\section{1 Empirical methods}

In recent years, the difference-in-difference (DID) model has been widely used to assess policy effects. In this paper, we treat the "Green Credit Guidelines" policy as an exogenous shock and construct a Quasi-natural experiment, in which the high-polluting and energy-intensive enterprises are regarded as the treatment group and other enterprises as the control group. Then, we can quantitatively measure the policy effects by comparing the green innovation behavior of the treatment group and control group before and after the policy implementation.

Due to the heterogeneity such as business scale and financial situation among different enterprises, if conducting the DID model directly, the empirical results may be biased and cannot reflect the real policy effects. In light of this, the propensity score matching method (PSM) and the difference-in-difference method (DID) 
are combined to solve this problem. PSM model is applied to match different types of enterprises to ensure that the treatment group and the control group can meet randomness and homogeneity requirements, and then the matched samples are used for DID analysis. The baseline model is as follows.

$$
\text { invtotal }_{i j}=\sigma \text { treat } \cdot \text { time }+\gamma X_{i j}+\alpha_{i}+\delta_{j}+\epsilon_{i j}
$$

In mode1 (1), invtotal $I_{i j}$ denotes the number of green patent grants in $i$ enterprise in year $j$. treat is the policy dummy variable, where treat is equal to 1 if the sample enterprise is high-polluting and energy-intensive, otherwise treat is equal to 0. time is the dummy variable for the treatment period. Since the "Green Credit Guidelines" policy was issued in 2012, time equals to 1 denotes the years 2012 and later, and time equals to0 denotes the years before 2012. The interaction term (namely treat*time) is the core variable, and its coefficient $\sigma$ measures the policy effects on the green innovation of high-polluting and energy-intensive enterprises. $X_{i j}$ denotes a set of characteristic variables of enterprises over time. $a_{i}, \delta_{j}$ and $\varepsilon_{i j}$ denote individual fixed effects, time fixed effects and the error term, respectively.

Besides, to investigate the impact mechanism of the "Green Credit Guidelines" policy on the green innovation of high-polluting and energy-intensive enterprises, the following mediation model is constructed with reference to Baron et al. (1986).

$$
\begin{gathered}
\text { invtotal }_{i j}=c \text { treat } \cdot \text { time }+\epsilon_{1} \\
M=a \text { treat } \cdot \text { time }+\epsilon_{2} \\
\text { invtotal }_{i j}=c^{\prime} \text { treat } \cdot \text { time }+b \cdot M+\epsilon_{3}
\end{gathered}
$$

In models (2)-(4), $M$ denotes the mediation variable. The mediation effect exists where the coefficients $a, b$, and $c$ are all significantly not equal to 0 . Therefore, if the coefficient $c$ ' is significantly not equal to 0 , it indicates a partial mediation effect. Otherwise, it indicates a complete mediation effect.

\section{2 Variables and data}

\section{2. 1 Dependent variable}

The number of green patent grants (invtotal $i_{i j}$ ) is the dependent variable. Existing literature usually uses R\&D investment or the number of patents to measure enterprises' innovation capacity since there are no uniform standards. Given that R\&D investment emphasizes the pre-innovation stage and cannot accurately measure enterprises' innovation output (Cruz-Cázares et al., 2013; Tumelero et al., 2019), green patents are introduced to reflect the innovation performance and real innovative capacity of enterprises more accurately. Referring to Guan et al. (2009) and Zhang et al. (2019), this paper uses the number of the authorized green patent to denote the enterprises' innovation capacity.

Further, green patents can be subdivided into green invention patents and green utility patents. Green invention patents represent substantial green technological innovation, while green utility patents represent non-substantial incremental innovation. Therefore, we use green invention patent grants ( invij $\left._{i j}\right)$ and green utility patent grants (invpra $a_{i j}$ ) as dependent variables for the robustness test and further refine the policy effects on enterprises' green innovation behavior.

\subsubsection{Independent variable}


High-polluting and energy-intensive enterprises under the policy of the "Green Credit Guidelines" (treat*time) is the independent variable. The "Green Credit Guidelines" policy is a vital component in promoting green finance development in China. It clearly sets out the policy boundaries, management methods, and assessment criteria for financial institutions especially commercial banks to carry out green credit business.

Therefore, this paper regards the "Green Credit Guidelines" policy as an exogenous shock to explore the policy effects on the green innovation performance of high-polluting and energy-intensive enterprises. The interaction term of the policy treatment group's dummy variable (treat) and the time dummy variable (time) represents the specific samples of high-polluting and energy-intensive enterprises under the period of implementation of the "Green Credit Guidelines" policy.

\subsection{Control variables}

Referring to Liu et al. (2019) and Wang et al. (2019), this paper includes the following variables in the empirical analysis to avoid estimation bias errors due to omitted variables. (1) The independence and objectivity of decision-making (indr). The percentage of independent directors measures the independence and objectivity of the enterprise's decision making. (2) Growth stage of the enterprise (growth). The growth rate of business revenue measures the enterprise's growth status and development ability. (3) Profitability (roa). The return on assets measures the enterprise's profitability. (4) Size of the enterprise(size). The logarithm of its total assets denotes the enterprise's size. (5) The intensity of environmental regulation (env). Following Levinson (1999), the intensity of environmental regulations is measured by a synthetic index of environmental regulations. (6) Enterprise supervision system (dual). The enterprise supervision system is measured by the chairman and general manager's concurrent appointment, with dual equal to 1 if the chairman does not also serve as general manager, otherwise dual equal to 0. (7) The cumbersomeness of enterprise's decision-making (board). The logarithm of the number of shareholders measures the enterprise's decision-making cumbersomeness.

The following variables are introduced as mediator variables in the mechanism test. (1) Financing constraints (sa). Referring to Hadlock et al. (2009), the financing constraints of the enterprise is measured by the SA index. (2) R\&D intensity (Inrd). The logarithm of R\&D investment measures the enterprise's R\&D intensity for innovative technologies.

\section{2. 4 Data source}

According to the IPC Green Inventory of the World Intellectual Property Organization, we select the green patent data of Chinese listed enterprises from the patent database of the State Intellectual Property Office of China (SIP0), including green invention patent grants and green utility patents. The control variables' original data are from the China Stock Market \& Accounting Research Database (CSMAR). Referring to the data processing method Brandt et al. (2012), we eliminate the observations with obvious statistical errors or non-compliance with accounting standards, and finally obtain our research dataset. 


\section{3 Descriptive statistics}

This paper is mainly based on the balanced panel data of 1171 listed enterprises from 2006-2018, and the summary of the main variables are reported in Table 1. It shows that after implementing the "Green Credit Guidelines" policy, the number of high-polluting and energy-intensive enterprises' green patent grants, green invention patent grants, and green utility patent grants have increased in varying degrees. Therefore, we verify whether there is a causal relationship between the "Green Credit Guidelines" policy and enterprises' innovation behavior in the following sections.

Table1.Summary statistics of major variables

\begin{tabular}{|c|c|c|c|c|c|}
\hline \multirow[b]{2}{*}{ Variables } & \multirow[b]{2}{*}{ Sample } & \multicolumn{2}{|c|}{ Green Enterprises } & \multicolumn{2}{|c|}{ "Two-High" Enterprises } \\
\hline & & Mean & Std.dev & Mean & Std.dev \\
\hline \multirow[t]{2}{*}{ invtotal } & Before policy & 0.35 & 4.57 & 0.20 & 1.51 \\
\hline & After policy & 1.53 & 19.46 & 0.74 & 6.04 \\
\hline \multirow[t]{2}{*}{$i n v$} & Before policy & 0.18 & 3.81 & 0.06 & 0.47 \\
\hline & After policy & 0.86 & 15.13 & 0.22 & 1.02 \\
\hline \multirow[t]{2}{*}{ invpra } & Before policy & 0.17 & 0.30 & 0.14 & 1.17 \\
\hline & After policy & 0.67 & 5.64 & 0.52 & 5.81 \\
\hline$i n d r$ & Full sample & 0.37 & 0.05 & 0.36 & 0.05 \\
\hline growth & Full sample & 0.21 & 0.74 & 0.18 & 0.62 \\
\hline roa & Full sample & 0.02 & 0.09 & 0.03 & 0.09 \\
\hline size & Full sample & 9.56 & 9.67 & 9.55 & 0.62 \\
\hline env & Full sample & 0.71 & 1.00 & 1.13 & 1.69 \\
\hline dual & Full sample & 0.86 & 0.35 & 0.83 & 0.37 \\
\hline board & Full sample & 10.61 & 0.85 & 10.61 & 0.86 \\
\hline
\end{tabular}

396

\section{Empirical results and discussion}

\section{1 Propensity score matching}

In this paper, high-polluting and energy-intensive enterprises are regarded as the treatment group and environment-friendly enterprises are regarded as the control group. Seven observable variables, including the independence and objectivity of decision-making (indr), the growth stage of the enterprise (growth), the profitability (roa), the size of the enterprise (size), the intensity of environmental regulation (env), the enterprises' supervision system(dual), and the cumbersomeness of enterprise's decision-making (board) are selected as the matching indexes of the PSM model. We use the Probit model to estimate the propensity scores 
and then match enterprises by Nearest Matching Method. Finally, we get 595 enterprises matched in total, including 333 from the treatment group and 262 from the control group.

We implement a balance test to ensure no significant difference between the treatment and control groups after matching. Table 2 shows the balance test results. Before propensity score matching, independent decision-making ability (indr), profitability (roa) and environmental regulatory intensity (env) all differ at the $5 \%$ level of significance, while all variables do not differ significantly after matching, and the distribution of each variable is more similar within the treatment and control groups. This suggests that the matched enterprises have similar characteristics in 2012, meeting randomness and homogeneity requirements for the difference-in-difference approach.

Table2.Balance test for Propensity Score Matching

\begin{tabular}{|c|c|c|c|c|c|c|}
\hline \multirow[b]{2}{*}{ Variables } & \multirow[b]{2}{*}{ Matching } & \multicolumn{2}{|c|}{ Treatment group } & \multicolumn{2}{|c|}{ Control group } & \multirow[b]{2}{*}{ P-value } \\
\hline & & Mean & Std.dev & Mean & Std.dev & \\
\hline \multirow[t]{2}{*}{$i n d r$} & before & 0.36 & 0.05 & 0.37 & 0.06 & $0.013 * *$ \\
\hline & after & 0.36 & 0.05 & 0.36 & 0.05 & 0.817 \\
\hline \multirow[t]{2}{*}{ growth } & before & 0.24 & 0.59 & 0.26 & 0.85 & 0.633 \\
\hline & after & 0.24 & 0.60 & 0.31 & 1.07 & 0.276 \\
\hline \multirow[t]{2}{*}{ roa } & before & 0.03 & 0.11 & 0.04 & 0.06 & $0.018^{* *}$ \\
\hline & after & 0.03 & 0.09 & 0.03 & 0.06 & 0.696 \\
\hline \multirow[t]{2}{*}{ size } & before & 9.58 & 0.61 & 9.57 & 0.62 & 0.823 \\
\hline & after & 9.60 & 0.60 & 9.61 & 0.58 & 0.830 \\
\hline \multirow[t]{2}{*}{ env } & before & 1.11 & 1.18 & 0.68 & 0.61 & $0.001 * * *$ \\
\hline & after & 0.90 & 0.60 & 0.85 & 0.64 & 0.382 \\
\hline \multirow[t]{2}{*}{ dual } & before & 0.84 & 0.37 & 0.87 & 0.34 & 0.231 \\
\hline & after & 0.84 & 0.37 & 0.85 & 0.35 & 0.635 \\
\hline \multirow[t]{2}{*}{ board } & before & 10.76 & 0.90 & 10.72 & 0.87 & 0.476 \\
\hline & after & 10.74 & 0.90 & 10.75 & 0.87 & 0.828 \\
\hline
\end{tabular}

\section{2 Difference-in-difference mode1}

\section{2. 1 Parallel trend assumption test}

A vital prerequisite of the DID model is that the treatment and control groups have similar trends before the exogenous policy shock (Bertrand et al., 2004), which 
performance should be excluded.

To test whether the treatment and control groups have a parallel trend before the policy shock, we plot the trend of the average number of green patent grants for high-polluting and energy-intensive enterprises and environmental-friendly enterprises from 2006 to 2018. Figure 2 shows that before the implementation of the "Green Credit Guidelines", the average number of green patent grants in the treatment and control groups maintain a similar fluctuating upward trend. After implementing the policy, the treatment group's overall increase is significantly larger than the control group.

Figure 2 indicates that the treatment and control groups which meet the paralle1 trend assumption. Therefore, it can tentatively infer that the "Green Credit Guidelines" policy improves high-polluting and energy-intensive enterprises' green innovation performance.

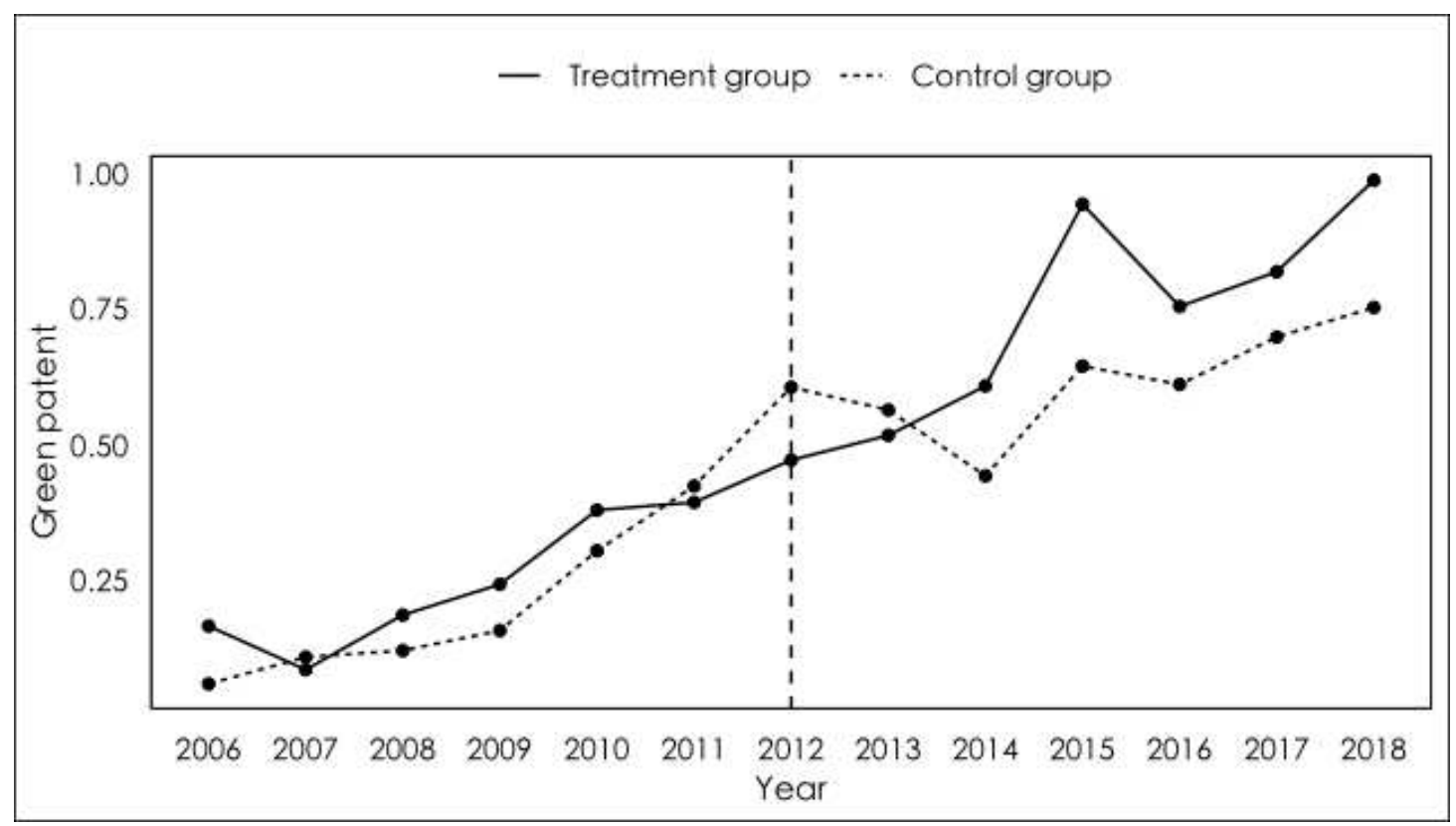

440

Fig. 2. Dynamic trends of the number of green patents

Further, an empirical equation is set up for the parallel trend test (Liu et al., 2016). The equation is as follows.

$$
\text { invtotal }_{i j}=\sigma_{k} \sum_{k \geq-6}^{6+} \text { treat } \cdot \text { time }_{2012+k}+\gamma X_{i j}+\alpha_{i}+\delta_{j}+\epsilon_{i j}
$$

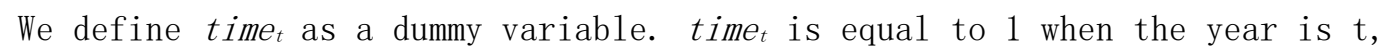
otherwise time $_{t}$ is equal to 0 . Other variables are consistent with the baseline regression (1). The results of the regression are shown in Figure 3. It can be seen that the regression coefficients are not significant until 2012, while the regression coefficients become significant and gradually increase after 2012. This suggests that before implementing the "Green Credit Guidelines" policy, the trends of treatment and control groups have no significant difference. After 2012, the number of green patents in the treatment and control groups shows a significant difference. Therefore, the empirical results are consistent with the inference of Figure 2, which proves that the research sample conforms to the parallel trend assumption. 


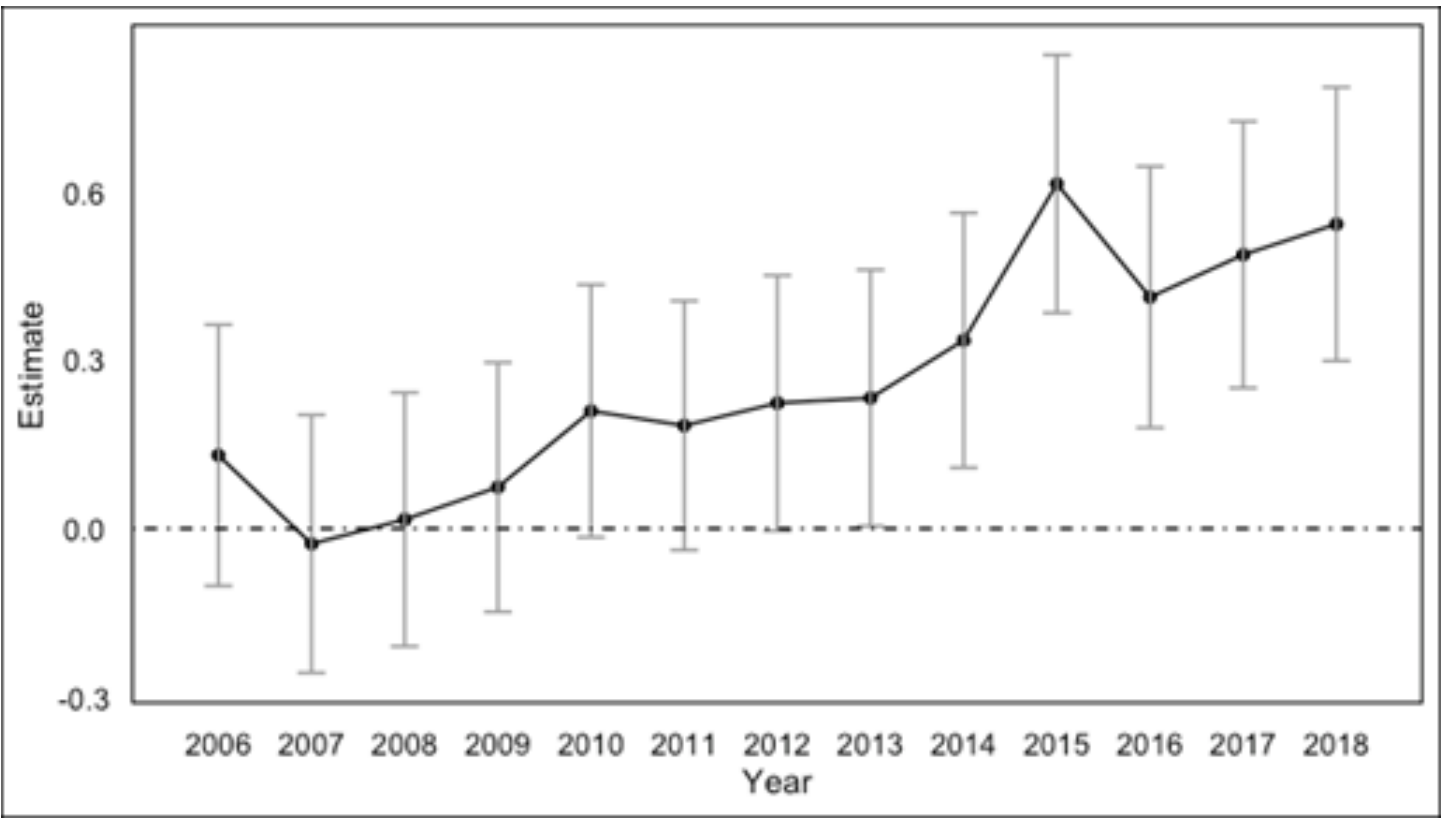

Fig. 3.Test of parallel trend ${ }^{1}$

\subsubsection{Average treatment effects and marginal treatment effects}

According to the baseline regression (1), we can measure the policy's average treatment effects to assess the overall impact of the "Green Credit Guidelines" policy on high-polluting and energy-intensive enterprises' green innovation performance. However, the marginal effect of this policy cannot be assessed. To further explore whether the policy impact is time-lagged and persistent, equation (1) is extended as follows (Fan et al., 2012).

$$
\text { invtotal }_{i j}=\sigma_{k} \sum_{k \geq 0}^{6+} \text { treat } \cdot \text { time }_{2012+k}+\gamma X_{i j}+\alpha_{i}+\delta_{j}+\epsilon_{i j}
$$

Based on the research sample matched through PSM, we evaluate the policy effects of the "Green Credit Guidelines" based on equation (1) and equation (6), and the results are reported in columns (1) and (2) of Table 3, respectively. In column (1), the coefficient of the interaction term treat*time is positive at the $1 \% 1$ evel of significance. In column (2), the coefficients interaction term's coefficients in the first two years after the implementation of the policy are not significant. However, the interaction term's coefficients from 2014 to 2018 are all positive at the $5 \%$ level of significance.

The empirical results suggest that the implementation of the "Green Credit Guidelines" policy can promote the green technology innovation of high-polluting and energy-intensive enterprises overall.

Meanwhile, the policy effects show a specific time lag. The potential reason for this result is that the effect of green credit on green innovation of enterprises requires a higher degree of maturity of market development, so it has a certain "time lag" effect. Furthermore, the empirical results also show that the "Green Credit Guidelines" can persistently promote high-polluting and energy-intensive

${ }^{1}$ The gray line in the figure indicates the $90 \%$ confidence interval for the regression coefficient. 
Table3. Regression results for DID model

(1)

\begin{tabular}{|c|c|c|}
\hline \multirow[b]{2}{*}{ Variables } & \\
\hline & \multicolumn{2}{|c|}{ invtotal } \\
\hline \multirow[t]{2}{*}{ treat*time } & $0.2955^{* * *}$ & \\
\hline & $(5.2521)$ & \\
\hline \multirow[t]{2}{*}{ treat $*$ timezo12 } & & 0.1332 \\
\hline & & (1.3270) \\
\hline \multirow[t]{2}{*}{ treat $^{*}$ time $_{2013}$} & & 0.1419 \\
\hline & & (1.3929) \\
\hline \multirow[t]{2}{*}{ treat*time 2014} & & $0.2453 * *$ \\
\hline & & $(2.3984)$ \\
\hline \multirow[t]{2}{*}{ treat $*$ time 2015} & & $0.5229 * * *$ \\
\hline & & $(5.0121)$ \\
\hline \multirow[t]{2}{*}{ treat*time 2016} & & $0.3208 * * *$ \\
\hline & & $(2.9981)$ \\
\hline \multirow[t]{2}{*}{ treat $^{*}$ time $_{2017}$} & & $0.3954 * * *$ \\
\hline & & $(3.5666)$ \\
\hline \multirow[t]{2}{*}{ treat*time2018 } & & $0.4507 * * *$ \\
\hline & & $(3.8602)$ \\
\hline \multirow[t]{2}{*}{ indr } & $1.9141 * * *$ & $1.8426 * * *$ \\
\hline & (3.5614) & (3.4277) \\
\hline \multirow[t]{2}{*}{ growth } & $-0.0785 * * *$ & $-0.0757 * *$ \\
\hline & $(-2.6389)$ & $(-2.5409)$ \\
\hline \multirow[t]{2}{*}{ roa } & -0.2415 & -0.2649 \\
\hline & $(-0.8541)$ & $(-0.9360)$ \\
\hline \multirow[t]{2}{*}{ size } & $0.4438 * * *$ & $0.4080^{* * *}$ \\
\hline & (5.9834) & $(5.4215)$ \\
\hline env & 0.0182 & 0.0143 \\
\hline
\end{tabular}


dual

$0.1947 * * *$

(2.7887)

$0.1047 * *$

(2.1516)
$0.1946^{* * *}$

$0.1061 * *$

(2.1765)

\begin{tabular}{lcl}
\hline Fixedeffects & YES & YES \\
\hline
\end{tabular}

Notes: $* \mathrm{p}<0.10, * * \mathrm{p}<0.05, \quad * * * \mathrm{p}<0.01$.

\subsubsection{Impact Mechanism}

According to equations (2)-(4), we construct a mediation model to investigate the impact mechanism of the "Green Credit Guidelines" policy on enterprises' green innovation behavior. Moreover, the bootstrap method is introduced to ensure that the empirical results are more reliable (Zhao et al., 2010). The estimation results are reported in Table 4.

Through causal steps regression, the interaction term' s coefficients in columns (1)-(4) are positive at the $1 \%$ level of significance, and the interaction term's coefficient in column (5) is not significant. The coefficient of SA index is negative, while the coefficient of R\&D investment is positive, both significant at the $1 \% 1$ eve1. Moreover, in the bootstrap test, the direct effect coefficient is 0.3261 and the mediation effect coefficient is -0.1529 , both significant at the $1 \% 1$ level. Besides, in the R\&D incentive mechanism, only the intermediate effect is significant at the $1 \%$ level, while the direct effect is not significant.

The empirical results obtained by the causal steps regression method and the bootstrap method are consistent. This suggests that the mechanism of financing constraints has a partial mediation effect, and the green credit policy's positive direct effect is larger than the negative mediation effect, while the R\&D incentive mechanism has a positive complete mediation effect.

Therefore, the "Green Credit Guidelines" policy stimulates high-polluting and energy-intensive enterprises to develop green technologies, but in contrast, it makes enterprises face a shortage of funds for green technology research and development by aggravating their financing constraints. Moreover, since the R\&D is a complete mediator while the financing constraints have a partial mediation effect, it suggests that the realization of the financing constraint mechanism relies on the R\&D incentive mechanism. It means that essentially both mechanisms affect enterprises' green innovation behavior through changing the enterprises' R\&D investment. Figure 4 illustrates the mechanism paths of Green Credit Guidelines and Green Innovation.

Table 4. Mechanism test results

(1)

(2)

(3)

(4)

(5) 


\begin{tabular}{|c|c|c|c|c|c|}
\hline Variables & invtotal & $s a$ & invtotal & $r d$ & invtotal \\
\hline treat*time & $0.1731 * * *$ & $0.1434 * * *$ & $0.3261 * * *$ & $0.2979 * * *$ & -0.0845 \\
\hline$s a$ & & & $-1.0664 * * *$ & - & - \\
\hline$r d$ & & - & - & & $0.2157 * * *$ \\
\hline Bootstrap mediating effect & - & \multicolumn{2}{|c|}{$-0.1529 * * *$} & \multicolumn{2}{|c|}{$0.0643 * * *$} \\
\hline Bootstrap direct effect & - & \multicolumn{2}{|c|}{$0.3261 * * *$} & \multicolumn{2}{|c|}{-0.0845} \\
\hline Bootstrap total effect & - & \multicolumn{2}{|c|}{$0.1731 * * *$} & \multicolumn{2}{|c|}{-0.0202} \\
\hline Prop. mediated & - & \multicolumn{2}{|c|}{$-0.8832 * * *$} & \multicolumn{2}{|c|}{-3.1840} \\
\hline Control variables & YES & \multicolumn{2}{|c|}{ YES } & \multicolumn{2}{|c|}{ YES } \\
\hline
\end{tabular}

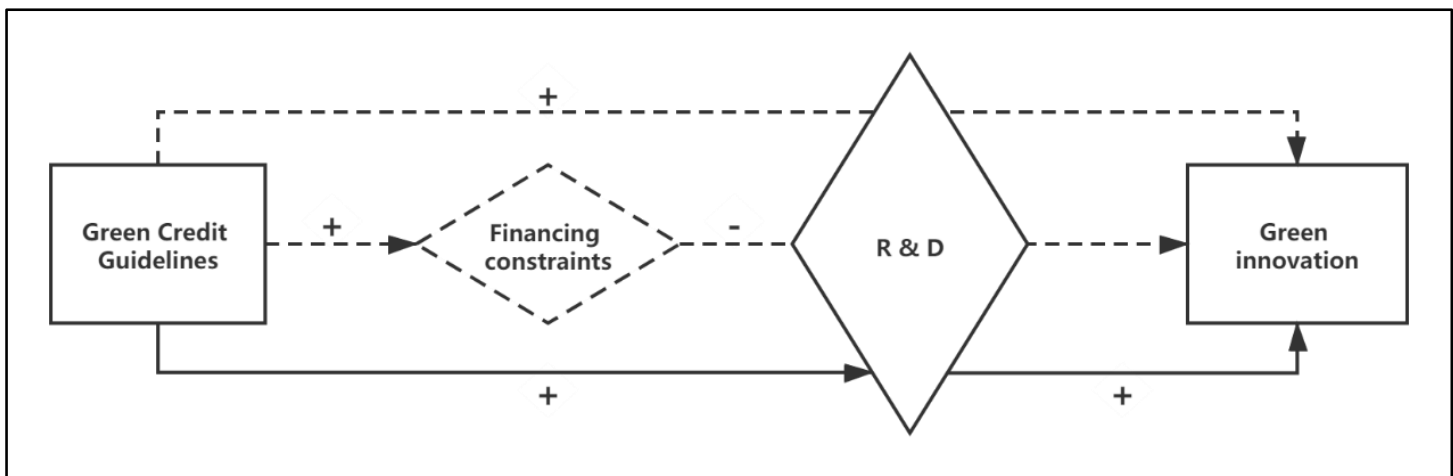

Fig.4. Green Credit Guidelines and Green Innovation: Mechanism path ${ }^{2}$

\section{3 Robustness test}

In this subsection, we present a series of robustness tests on the above empirical results. Specifically, we check the robustness by replacing the variables, altering the observation period, and adding other policy dummy variables.

\subsection{Replacing variables}

Referring to Liu et al. (2019), we replace the dependent variable green patent grants (invtotal $1_{i j}$ ), using green invention patent grants (invij) and green utility patent grants (invpra $i_{i j}$ ) as proxy variables for enterprises' green innovation behavior.

Table 5 shows that the average treatment effect of the "Green Credit Guidelines" policy on green innovation performance of high-polluting and energy-intensive enterprises remains significantly positive regardless of the dependent variable is green invention patent grants or green utility patent grants. The marginal effect is not significant in the first two years after the implementation of the green credit policy, but it becomes positive at least at the $10 \%$ level of significance in the

\footnotetext{
${ }^{2}$ The dotted line represents financing constraints mechanism, the solid line represents R\&D incentives mechanism.
} 
following five years. It can be seen that the test results are consistent with the previous results, suggesting that our findings are robust.

Furthermore, we find that the average treatment effect coefficient in column (1) of Table 5 is 0.1093 , smaller than 0. 1862 in column (3). Moreover, the marginal effect coefficients in column (2) are smaller than those in column (4) in most years. This suggests that the "Green Credit Guidelines" policy has different impacts on different types of green innovation behavior. Therefore, under the incentive of green credit policy, the number of non-invention patents increases more obviously than that of invention patents. The possible reason is that Chinese commercial banks currently lack the fine definition of high-quality green patents, which may prompt enterprises to implement the quantity competition strategy of green patents for seeking more financial support and credit resources. Enterprises are more likely to develop non-substantive green utility patents, probably because substantive green innovation patents have longer pay off periods, higher uncertainty risk, and greater execution difficulty. Thus, high-polluting and energy-intensive enterprises are less willing to undertake substantive green innovation in the cost-benefit trade-off.

In summary, under the "Green Credit Guidelines" policy, to obtain more green credit support, enterprises have motivations to adopt speculative innovation strategy, manifesting the scale of green patents, especially non-invention patents increase significantly.

Table 5. Robustness test results (by replacing variables)

\begin{tabular}{|c|c|c|c|c|}
\hline \multirow[b]{2}{*}{ Variables } & (1) & (2) & (3) & (4) \\
\hline & \multicolumn{2}{|c|}{ inv } & \multicolumn{2}{|c|}{ invpra } \\
\hline \multirow[t]{2}{*}{ treat*time } & $0.1093 * * *$ & & $0.1862 * * *$ & \\
\hline & $(4.6074)$ & & $(4.0976)$ & \\
\hline \multirow[t]{2}{*}{ treat $*$ time $_{2012}$} & & 0.0622 & & 0.0711 \\
\hline & & (1.4689) & & $(0.8766)$ \\
\hline \multirow[t]{2}{*}{ treat*time 2013} & & 0.0617 & & 0.0802 \\
\hline & & $(1.4360)$ & & $(0.9753)$ \\
\hline \multirow[t]{2}{*}{ treat $*$ time 2014} & & $0.0962 * *$ & & $0.1491 *$ \\
\hline & & $(2.2306)$ & & $(1,8058)$ \\
\hline \multirow[t]{2}{*}{ treat $*$ time 2015} & & $0.0751^{*}$ & & $0.4478 * * *$ \\
\hline & & $(1.7080)$ & & $(5.3159)$ \\
\hline \multirow[t]{2}{*}{ treat $*$ time 2016} & & $0.1695 * * *$ & & $0.1512 *$ \\
\hline & & $(3.7582)$ & & (1.7509) \\
\hline
\end{tabular}




\begin{tabular}{|c|c|c|c|c|}
\hline \multirow[t]{2}{*}{ treat*time 2017} & & \multicolumn{2}{|l|}{$0.2379 * * *$} & $0.1575^{*}$ \\
\hline & & \multicolumn{2}{|l|}{ (5.0894) } & (1.7599) \\
\hline \multirow[t]{2}{*}{ treat*time 2018} & & \multicolumn{2}{|l|}{$0.1192 * *$} & $0.3314 * * *$ \\
\hline & & \multicolumn{2}{|l|}{$(2.4227)$} & $(3.5159)$ \\
\hline \multirow[t]{2}{*}{ indr } & $0.5872 * * *$ & $0.5807 * *$ & $1.3269 * * *$ & $1.2619 * * *$ \\
\hline & $(2.5914)$ & $(2.5622)$ & $(3.0567)$ & (2.9074) \\
\hline \multirow[t]{2}{*}{ growth } & -0.0179 & -0.0194 & $-0.0607 * *$ & $-0.0563 * *$ \\
\hline & $(-1.4247)$ & $(-1.5457)$ & $(-2.5235)$ & $(-2.3399)$ \\
\hline \multirow[t]{2}{*}{ roa } & -0.0817 & -0.1013 & -0.1589 & -0.1636 \\
\hline & $(-0.6853)$ & $(-0.8486)$ & $(-0.6997)$ & $(-0.7161)$ \\
\hline \multirow[t]{2}{*}{ size } & $0.1753^{* * *}$ & $0.1599 * * *$ & $0.2686^{* * *}$ & $0.2482 * * *$ \\
\hline & $(5.6040)$ & $(5.0383)$ & $(4.4828)$ & (4.0839) \\
\hline \multirow[t]{2}{*}{ env } & 0.0038 & 0.0022 & 0.0144 & 0.0120 \\
\hline & $(0.4537)$ & $(0.2698)$ & $(0.9078)$ & $(0.7539)$ \\
\hline \multirow[t]{2}{*}{ dual } & $0.0591 *$ & $0.0606 * *$ & $0.1357 * *$ & $0.1340 * *$ \\
\hline & $(2.0063)$ & (2.0599) & $(2.4054)$ & $(2.3771)$ \\
\hline \multirow[t]{2}{*}{ board } & 0.0184 & 0.0207 & $0.0854 * *$ & $0.0854 * *$ \\
\hline & $(0.9437)$ & (1.0071) & $(2.1713)$ & (2.1697) \\
\hline Fixed effects & YES & YES & YES & YES \\
\hline
\end{tabular}

Notes: $* \mathrm{p}<0.10, * * \mathrm{p}<0.05, * * * \mathrm{p}<0.01$.

\section{3.2 Altering the observation period}

To avoid the possible randomness error caused by a single observation period, we replace the experimental and control groups' observation periods with 2007-2017, 2008-2016, and 2009-2015, respectively. And then, we re-evaluate the "Green Credit Guidelines" policy effects on the number of green patents of high-polluting and energy-intensive enterprises.

Table 6 shows the results during varied observation periods. The interaction term' s coefficient is significantly positive at the $1 \%$ level of significance despite the observation periods, and the marginal effect coefficients become significantly positive at the $5 \%$ level of significance from the third year of policy implementation. This indicates that the "Green Credit Guidelines" policy effects on green innovation performance of high-polluting and energy-intensive enterprises do not change

573 fundamentally during different sample observation periods. Therefore, these empirical results prove the robustness again. 
Table 6. Robustness test results (by altering observation periods)

\begin{tabular}{|c|c|c|c|c|c|c|}
\hline \multirow{3}{*}{$\frac{\text { Variables }}{\text { treat } * \text { time }}$} & \multicolumn{2}{|c|}{$2007-2017$} & \multicolumn{2}{|c|}{ 2008-2016 } & \multicolumn{2}{|c|}{ 2009-2015 } \\
\hline & \multicolumn{2}{|c|}{ invtotal } & \multicolumn{2}{|c|}{ invtotal } & \multicolumn{2}{|c|}{ invtotal } \\
\hline & $0.2713 * * *$ & & $0.2339 * * *$ & & $0.2008 * * *$ & \\
\hline & $(4.8269)$ & & $(3.9930)$ & & $(0.0019)$ & \\
\hline \multirow[t]{2}{*}{ treat $*$ time $_{2012}$} & & 0.1296 & & 0.1078 & & 0.0768 \\
\hline & & $(1.3689)$ & & (1.1763) & & $(0.8301)$ \\
\hline \multirow[t]{2}{*}{ treat $*$ time 2013} & & 0.1352 & & 0.1133 & & 0.0923 \\
\hline & & $(1.4053)$ & & $(1.2128)$ & & $(0.9742)$ \\
\hline \multirow{2}{*}{ treat $^{*}$ time 2014} & & $0.2342 * *$ & & $0.2200 * *$ & & $0.2031 * *$ \\
\hline & & $(2.4171)$ & & $(2.3258)$ & & $(2.1010)$ \\
\hline \multirow[t]{2}{*}{ treat $*$ time 2015} & & $0.5191 * * *$ & & $0.5058 * * *$ & & $0.4934 * * *$ \\
\hline & & $(5.2556)$ & & $(5.2476)$ & & (5.0087) \\
\hline \multirow[t]{2}{*}{ treat $*$ time 2016} & & $0.3119 * * *$ & & $0.2869 * * *$ & & \\
\hline & & (3.0759) & & $(2.8933)$ & & \\
\hline \multirow[t]{2}{*}{ treat $*$ time 2017} & & $0.3873 * * *$ & & & & \\
\hline & & (3.6819) & & - & & - \\
\hline \multirow[t]{2}{*}{ indr } & $1.8307 * * *$ & $1.7522 * * *$ & 0.5735 & 0.4791 & 0.1957 & 0.0447 \\
\hline & $(3.2448)$ & $(3.1056)$ & $(0.9219)$ & $(0.7703)$ & $(0.2687)$ & $(0.0614)$ \\
\hline \multirow[t]{2}{*}{ growth } & $-0.0744 * *$ & $-0.0706 * *$ & $-0.0665 * *$ & $-0.0601 *$ & -0.0459 & -0.0365 \\
\hline & $(-2.5258)$ & $(-2.3961)$ & $(-2.1568)$ & $(-1.9468)$ & $(-1.3250)$ & $(-1.0548)$ \\
\hline \multirow[t]{2}{*}{ roa } & -0.1936 & -0.2110 & -0.1542 & -0.1537 & -0.2632 & -0.2527 \\
\hline & $(-0.6537)$ & $(-0.7118)$ & $(-0.4830)$ & $(-0.4819)$ & $(-0.7145)$ & $(-0.6869)$ \\
\hline \multirow[t]{2}{*}{ size } & $0.4797 * * *$ & $0.4439 * * *$ & $0.4515^{* * *}$ & $0.4101 * * *$ & $0.3648 * * *$ & $0.3168^{* *}$ \\
\hline & $(5.9505)$ & $(5.4306)$ & $(4.7262)$ & $(4.2371)$ & $(3.0319)$ & $(2.4652)$ \\
\hline \multirow[t]{2}{*}{$e n v$} & 0.0164 & 0.0145 & $0.0619 * *$ & $0.0610 * *$ & 0.0403 & 0.0391 \\
\hline & $(0.8448)$ & $(0.7436)$ & $(2.5042)$ & $(2.4667)$ & $(1.5567)$ & $(1.5144)$ \\
\hline \multirow[t]{2}{*}{ dual } & $0.1800 *$ & $0.1798 * *$ & $0.1545^{*}$ & $0.1532 *$ & 0.1459 & 0.1441 \\
\hline & $(2.4897)$ & $(2.4882)$ & (1.9509) & $(1.9370)$ & (1.5679) & $(1.5515)$ \\
\hline
\end{tabular}




\begin{tabular}{ccccccc}
\hline board & 0.0652 & 0.0644 & 0.0830 & 0.0822 & 0.1209 & 0.1176 \\
& $(1.2136)$ & $(1.1951)$ & $(1.3632)$ & $(1.3451)$ & $(1.5588)$ & $(1.5088)$ \\
\hline Fixed effects & YES & YES & YES & YES & YES & YES \\
\hline
\end{tabular}

Notes: $* \mathrm{p}<0.10, * * \mathrm{p}<0.05, * * * \mathrm{p}<0.01$.

\subsubsection{Adding other policy dummy variables}

Since the green innovation behavior of high-polluting and energy-intensive enterprises can also be affected by other related policies, it may lead to estimation bias if we mis judge other policies' effects as the "Green Credit Guidelines" policy's effects. To identify and resolve this problem, we set the other two green credit-related policies during the sample observation period as policy dummy variables policyl ${ }^{3}$ and policy $2^{4}$, respectively, and add them into the regression equation for robustness test.

The results in Table 7 show that the interaction term' s coefficients have little change with the introduction of other policy dummy variables, and they are all significant at the $1 \%$ level, while the coefficients of the dummy policy variables are not significant. This result indicates that the other relevant policies have little interference effects with the "Green Credit Guidelines" policy. The conclusion of this treatment is consistent with our previous analysis.

Table7. Robustness test results (by adding policy variables)

\begin{tabular}{cccc}
\hline Variables & invtotal & invtotal & invtotal \\
\hline treat*time & $0.2796^{* * * *}$ & $0.2941^{* * *}$ & $0.2782^{* * * *}$ \\
& $(4.8536)$ & $(5.0771)$ & $(4.6961)$ \\
policy1 & -0.1297 & - & -0.1297 \\
& $(-1.2792)$ & & $(-1.2793)$ \\
policy2 & - & 0.0109 & 0.0111 \\
& & $(0.1044)$ & $(0.1058)$ \\
indr & $1.9083^{* * *}$ & $1.9150^{* * *}$ & $1.9092 * * *$ \\
& $(3.5507)$ & $(3.5623)$ & $(3.5516)$ \\
growth & $-0.0770^{* * *}$ & $-0.0786^{* * *}$ & $-0.0770^{* * *}$ \\
& $(-2.5844)$ & $(-2.6402)$ & $(-2.5858)$ \\
\hline
\end{tabular}

${ }^{3}$ policyl is "Opinions on Implementing Environmental Policies and Regulations to Prevent Credit Risks" which released by the State Environmental Protection Administration of China in 2007. ${ }^{4}$ policy2 is "Guidelines on Building a Green Financial System" which jointly issued by Seven ministries including the People's Bank of China and the Ministry of Finance of China in 2016. 


\begin{tabular}{cccc}
\hline roa & -0.2254 & -0.2416 & -0.2255 \\
& $(-0.7965)$ & $(-0.5845)$ & $(-0.7969)$ \\
size & $0.4348^{* * *}$ & $0.4435^{* * *}$ & $0.4348^{* * * *}$ \\
& $(5.8426)$ & $(5.9713)$ & $(5.8307)$ \\
env & 0.0182 & $0.0182^{* * *}$ & 0.0182 \\
& $(0.9221)$ & $(0.9259)$ & $(0.9235)$ \\
dual & $0.1955^{* * *}$ & $0.1948^{* * *}$ & $0.1955^{* * *}$ \\
& $(2.8002)$ & $(2.7887)$ & $(2.8002)$ \\
board & $0.1051^{* *}$ & $0.1048^{* * *}$ & $0.1052^{* * *}$ \\
& $(2.1591)$ & $(2.1525)$ & $(2.1601)$ \\
\hline Fixed effects & YES & YES & YES \\
\hline
\end{tabular}

595

596

Notes: $* \mathrm{p}<0.10, * * \mathrm{p}<0.05, * * * \mathrm{p}<0.01$

\section{4 Heterogeneous effects}

We explore differential treatment effects across high-polluting and energy-intensive enterprises in this subsection, specifically, SOEs versus non-SOEs and strong market power versus weak market power enterprises.

\subsection{Heterogeneous effects with respect to ownership pattern}

A recent study finds that the "Green Credit Guidelines" policy has heterogeneous effects on SOEs and non-SOEs (Liu et al., 2019). To verify this, we report the estimation results for the SOEs and non-SOEs subsamples in columns 1 and 2 of Table 8, respectively, to explore whether the green innovation behavior response to the "Green Credit Guidelines" policy differs by ownership pattern. The results show that the interaction term's coefficient for state-owned enterprises is significantly positive at the $1 \%$ level, while the interaction term's coefficient for non-state enterprises is not significant. It suggests that the "Green Credit Guidelines" policy significantly promotes state-owned high-polluting and energy-intensive enterprises to carry out green innovation, but the policy effects on non-state-owned enterprises are not pronounced.

The difference in policy effects of various ownership enterprises can be explained from the perspective of willingness and ability. On the one hand, in transition economies, the government and regulatory policies still have an important impact on the credit resources and technological innovation activities of state-owned enterprises. After the promulgation of the green credit policy, compared with non-state-owned enterprises, state-owned enterprises have stronger motivation and responsibility to cater for the implementation of the policy, so as to develop green technologies and obtain more credit resources. On the other hand, from the perspective of the government-enterprise relationship and comprehensive ability, state-owned enterprises have more advantages over nonstate-owned 
enterprises in terms of the ability to obtain green credit resources from banking institutions and the supporting conditions for carrying out green technology innovation activities (Liu et al., 2019). Therefore, the results reveal that the green credit policy has a more pronounced effect on the green innovation performance of state-owned enterprises.

\section{4. 2 Heterogeneous effects with respect to market power}

Since enterprises' innovation activities are closely related to market power(Chen Y. et al., 2013), we report the subsample estimation results for enterprises with strong and weak market power in columns 3 and 4 of Table 8 respectively, to further explore the heterogeneous policy effects across different market power. The estimation results show that the coefficient of the interaction term for weak market power enterprises is 0.3655 , which is at the $1 \%$ level of significance. In contrast, the coefficient of the interaction term for strong market power enterprises is not significant. This indicates that the "Green Credit Guidelines" policy can promote green innovation of weak market power enterprises but has no pronounced effect on strong market power enterprises.

The differential impact of green credit policies on enterprises with various market powers may be caused by different price elasticities of demand. According to the Monopoly Theory, enterprises with strong monopoly power usually face lower price elasticities of demand, and earn excess profits in the long run by raising prices and cutting production appropriately. Therefore, they rely less on bank credit and have fewer incentives to develop green innovation. In contrast, enterprises with weak market power face relatively fierce market competition and lower profits, thus having greater demands for external financing. Therefore, after the implementation of the "Green Credit Guidelines" policy, enterprises with weaker market power are more sensitive to the changes in the financing quota and financing costs compared with enterprises with strong market power. In light of this, enterprises with weaker market power are more motivated to seek to obtain preferential policy benefits through green innovations to alleviate financial pressure, thereby increasing the number of green innovation patents.

Table 8. Results of heterogeneous effects

(1)

(2)

(3)

(4)

\begin{tabular}{ccccc} 
& State-owned & Non state-owned & Strong market power & Weak market power \\
\cline { 2 - 5 } Variables & invtotal & invtotal & invtotal & invtotal \\
\hline \multirow{2}{*}{ treat*time } & $0.4672 * * *$ & -0.0653 & 0.0959 & $0.3655^{* * *}$ \\
& $(6.1233)$ & $(-0.8158)$ & $(0.8049)$ & $(5.5077)$ \\
\multirow{2}{*}{ indr } & $3.1944 * * *$ & -0.7030 & 1.6078 & $2.0350^{* * *}$ \\
& $(4.3225)$ & $(-0.9461)$ & $(1.5327)$ & $(3.1573)$ \\
growth & $-0.0892 * *$ & -0.0487 & $-0.0935 *$ & $-0.0843 * *$ \\
& $(-2.1170)$ & $(-1.2434)$ & $(-1.9145)$ & $(-2.0056)$ \\
\hline
\end{tabular}




\begin{tabular}{ccccc}
\hline roa & -0.4409 & -0.0371 & -0.5101 & -0.1279 \\
size & $(-0.9258)$ & $(-0.1181)$ & $(-0.8996)$ & $(-0.3820)$ \\
& $0.5161^{* * *}$ & $0.3667^{* * *}$ & $0.7843^{* * * *}$ & $0.3490^{* * *}$ \\
env & $(4.7793)$ & $(3.8713)$ & $(5.4122)$ & $(3.5727)$ \\
& 0.0263 & $-0.1152^{*}$ & 0.0117 & 0.0280 \\
dual & $(1.1840)$ & $(-1.8914)$ & $(0.3832)$ & $(1.0374)$ \\
& 0.1631 & $0.2188^{* * *}$ & $0.3709^{* * *}$ & 0.1177 \\
board & $(1.5154)$ & $(2.6290)$ & $(2.6270)$ & $(1.4231)$ \\
& $0.1386^{*}$ & $0.1053^{*}$ & -0.0075 & $0.1450^{* *}$ \\
\hline Fixed effects & $(1.8850)$ & $(1.7518)$ & $(-0.0751)$ & $(2.5048)$ \\
\hline
\end{tabular}

654

655

656

657

658

659

660

661

662

663

664

665

666

667

668

669

670

671

672

673

674

675

676

677

678

679

680

681

Notes: $* \mathrm{p}<0.10, * * \mathrm{p}<0.05, * * * \mathrm{p}<0.01$

\section{Conclusions}

More and more economies are beginning to attach importance to the role of green technological innovation in sustainable development, and are trying to promote green technological innovation by implementing financial support measures such as green credit policies. But has the existing green credit policy achieved the expected effect? What are the obstacles in the implementation of the green credit policy? How to overcome the problems of endogeneity and reverse causality between variables? Can green patent innovation be separated from general patent innovation in order to obtain more accurate empirical results? For the above-mentioned problems, existing research still lacks a comprehensive and objective framework of theoretical exploration and policy evaluation.

In view of this, based on the balanced panel data of China' s listed enterprises, we apply the PSM-DID model to study the policy effects and mechanisms of the "Green Credit Guidelines" policy on the green innovation performance of high-polluting and energy-intensive enterprises. Results suggest that the "Green Credit Guidelines" policy affects high-polluting and energy-intensive enterprises' green innovation behavior through mechanisms of financing constraints and R\&D incentives. Overall, this policy significantly promotes the green innovation performance of high-polluting and energy-intensive enterprises due to the incentive effect presents more pronounced than the constraint effect. We also verify that the policy effects of the "Green Credit Guidelines" policy are time-lagged while persistent. Furthermore, after the implementation of the "Green Credit Guidelines" policy, high-polluting and energy-intensive enterprises tend to improve their environmental performance through non-substantive green innovations rather than substantive green innovations. In addition to shorter R\&D cycles and lower technical requirements for non-invention patents, it is also related to the current selective green credit 
policy. The policy lacks a reified definition of high-quality patents, and mainly encourages enterprises to carry out speculative innovation behavior. Enterprises are likely to focus more on increasing the "quantity" of green innovation to seek more credit support, while may ignore the improvement of the "quality" of green innovation. Finally, the "Green Credit Guidelines" policy has heterogeneous effects on the enterprises' green innovation behavior across ownership property and market power, respectively, with a more pronounced effect for state-owned enterprises and weaker market power enterprises.

There are some policy implications based on the above conclusions. First of all, it is necessary to further improve the financial support of the green credit policy to environmental-friendly enterprises and technologies, carry out refined classification and differentiated management of the green patent achievement standards, clarify the support objects and the technical scopes, and guide the flow of funds to environment-friendly patents and green transition of high-polluting and energy-intensive enterprises. Secondly, considering the heterogeneous characteristics of regions and enterprises, it should not be one size fits all. The relevant departments should strengthen the green credit policy support for non-state-owned enterprises and small and medium-sized enterprises (SMEs), while adhering to the fairness, openness and transparency of the green credit policy, and further regulate the green credit resources obtained by the state-owned enterprises and large enterprises of high-polluting and energy-intensive industries. Finally, the government should create a good social environment and supporting the policy system for the implementation of green credit policy. Specifically, it needs to expand the financing sources for green technology innovation, ease enterprises' financing constraints and increase investment in green technologies, thereby accelerate the transformation of high-polluting and energy-intensive enterprises into intelligent, green, and service-oriented enterprises.

\section{Declarations}

\section{-Ethics approval and consent to participate}

Not applicable.

\section{-Consent for publication}

Not applicable.

\section{-Authors' contributions}

The authors confirm contribution to the paper as follows: Conceptualization, S. L., R. X. and X.C. ; methodology, R.X., S. L. ; software, R. X. ; formal analysis, S. L., R. X. and X.C. ; investigation, S. L., R.X. and X.C. ; writing-original draft preparation, R.X., S. L. ; writing-review and editing, S. L., R.X. and X. C. ; visualization, R. X. ; supervision, S. L., R.X. ; funding acquisition, S. L., X. C. A11 authors have read and agreed to the published version of the manuscript.

\section{-Competing interests}

The authors declare that they have no competing interests.

-Funding

This research work is supported in part by grants from National Natural Science 
Foundation of China (71803033), Humanity and Social Science Youth foundation of Ministry of Education of China (18YJC790101), Soft Science Project of Guangdong Province (2019A101002060), Natural Science Foundation of Guangdong Province (2019A1515011581), Philosophy and Social Sciences Planning Project of Guangdong Province (GD20SQ12), Guangzhou Philosophy and Social Science Planning Project (2020GZYB42, 2020GZGJ158), and Educational Science Planning Project of Guangdong Province (2019GXJK079).

- Availability of data and materials

All data generated or analysed during this study are included in this article.

\title{
- Author's information
}

\author{
1. Sheng Liu \\ (Emai1: gdufsliusheng@126. com)
}

Institute of Studies for the Greater Bay Area, Guangdong University of Foreign Studies.

\section{Rongxin $\mathrm{Xu}$}

(Corresponding author. Email: xu. rongxin@connect.um. edu. mo) Faculty of Social Science, University of Macau.

\section{Xiuying Chen}

(Emai1: chenxiuying1128@163.com)

School of Economics and Trade, Guangdong University of Finance.

\section{References:}

Aghion P, Askenazy P, Berman N, et al. Credit constraints and the cyclicality of R\&D investment: Evidence from France[J]. Journal of the European Economic Association, 2012, 10(5): 1001-1024.

Baron R M, Kenny D A. The moderator-mediator variable distinction in social psychological research: Conceptual, strategic, and statistical considerations[J]. Journal of personality and social psychology, 1986, 51(6): 1173.

Bertrand M, Duflo E, Mullainathan S. How much should we trust differences-in-differences estimates?[J]. The Quarterly journal of economics, 2004, 119(1): 249-275.

Brandt L, Van Biesebroeck J, Zhang Y. Creative accounting or creative destruction? Firm-level productivity growth in Chinese manufacturing[J]. Journal of development economics, 2012, 97(2): 339-351.

Cecere G, Corrocher N, Mancusi M L. Financial constraints and public funding of eco-innovation: empirical evidence from European SMEs[J]. Small Business Economics, 2020, 54(1): 285-302.

Chen Y, Schwartz M. Product innovation incentives: Monopoly vs. competition[J]. Journal of Economics \& Management Strategy, 2013, 22(3): 513-528.

Cruz-Cázares C, Bayona-Sáez C, García-Marco T. You can't manage right what you can't measure well: Technological innovation efficiency[J]. Research policy, 2013, 42(6-7): 1239-1250. 

Strategic Management, 2015, 27(7): 782-808.

Fan S, Li L, Zhang X. Challenges of creating cities in China: Lessons from a short-lived county-to-city upgrading policy[J]. Journal of Comparative Economics, 2012, 40(3): 476-491.

Foster, C, and Green, K. Greening the innovation process[J]. Business Strategy and the Environment, 2000, 9(2):287-303.

Ghisetti C, Mancinelli S, Mazzanti M, et al. Financial barriers and environmental innovations: evidence from EU manufacturing firms[J]. Climate Policy, 2017, 17(sup1): S131-S147.

Gray W B, Shadbegian R J. Pollution abatement costs, regulation, and plant-level productivity[R]. National Bureau of Economic Research, 1995.

Guan J C, Richard C M, Tang E P Y, et al. Innovation strategy and performance during economic transition: Evidences in Beijing, China[J]. Research policy, 2009, 38(5): 802-812.

Hadlock C J, Pierce J R. New evidence on measuring financial constraints: Moving beyond the KZ index[J]. The Review of Financial Studies, 2010, 23(5): 1909-1940.

Heckman J J, Ichimura H, Todd P E. Matching as an econometric evaluation estimator: Evidence from evaluating a job training programme[J]. The review of economic studies, 1997, 64(4): 605-654. policy, 2008, 37(1): 163-173. the economy, 2004, 4: 35-68.

Kang H, Jung S Y, Lee H. The impact of Green Credit Policy on manufacturers' efforts to reduce suppliers' pollution[J]. Journal of Cleaner Production, 2020, 248: 119271.

Kapoor S, Oksnes L, Hogarth R. Funding the green new deal: building a green financial system[J]. Green European Foundation.Green New Deal Series, 2011, 6. 2012, 41(5): 862-870. credit[J]. Journal of Financial and quantitative analysis, 2010: 555-587. 

Univ. of Wisconsin, Madison, WI, 1999.

795 Li Z, Liao G, Wang Z, et al. Green loan and subsidy for promoting clean production innovation[J]. Journal of 796 Cleaner Production, 2018, 187: 421-431.

797 Liu J Y, Xia Y, Fan Y, et al. Assessment of a green credit policy aimed at energy-intensive industries in China based on a financial CGE model[J]. Journal of Cleaner Production, 2017, 163: 293-302.

Liu Q, Qiu L D. Intermediate input imports and innovations: Evidence from Chinese firms' patent filings[J]. evidence from China[J]. Finance Research Letters, 2019, 29: 129-135.

Magnusson P R. Benefits of involving users in service innovation[J]. European Journal of Innovation Management, 2003, 6(4):228-238.

Porter M, Van der Linde C. Green and competitive: ending the stalemate[J]. The Dynamics of the eco-efficient economy: environmental regulation and competitive advantage, 1995, 33. Relationship[J]. Journal of Economic Perspectives, 9, 9(4): 97-118.

Tsai K H, Liao Y C. Sustainability strategy and eco-innovation: A moderation model[J]. Business Strategy and the Environment, 2017, 26(4): 426-437.

811 Tumelero C, Sbragia R, Evans S. Cooperation in R \& D and eco-innovations: The role in companies' socioeconomic performance[J]. Journal of Cleaner Production, 2019, 207: 1138-1149.

813 Wang E, Liu X, Wu J, et al. Green Credit, Debt Maturity, and Corporate Investment—Evidence from China[J]. 814 Sustainability, 2019, 11(3): 583.

815 Wang F, Yang S, Reisner A, et al. Does Green Credit Policy Work in China? The Correlation between Green Credit 816 and Corporate Environmental Information Disclosure Quality[J]. Sustainability, 2019, 11(3): 733.

817 Xu X, Li J. Asymmetric impacts of the policy and development of green credit on the debt financing cost and 818 maturity of different types of enterprises in China[J]. Journal of Cleaner Production, 2020: 121574.

819 Zhang D, Rong Z, Ji Q. Green innovation and firm performance: evidence from listed companies in China[J].

820 Resources, Conservation and Recycling, 2019, 144: 48-55.

821 Zhang Y, Xing C, Wang Y. Does green innovation mitigate financing constraints? Evidence from China's private 822 enterprises[J]. Journal of Cleaner Production, 2020: 121698. 
823 Zhao X, Lynch Jr J G, Chen Q. Reconsidering Baron and Kenny: Myths and truths about mediation analysis[J].

824 Journal of consumer research, 2010, 37(2): 197-206.

825 
Figures

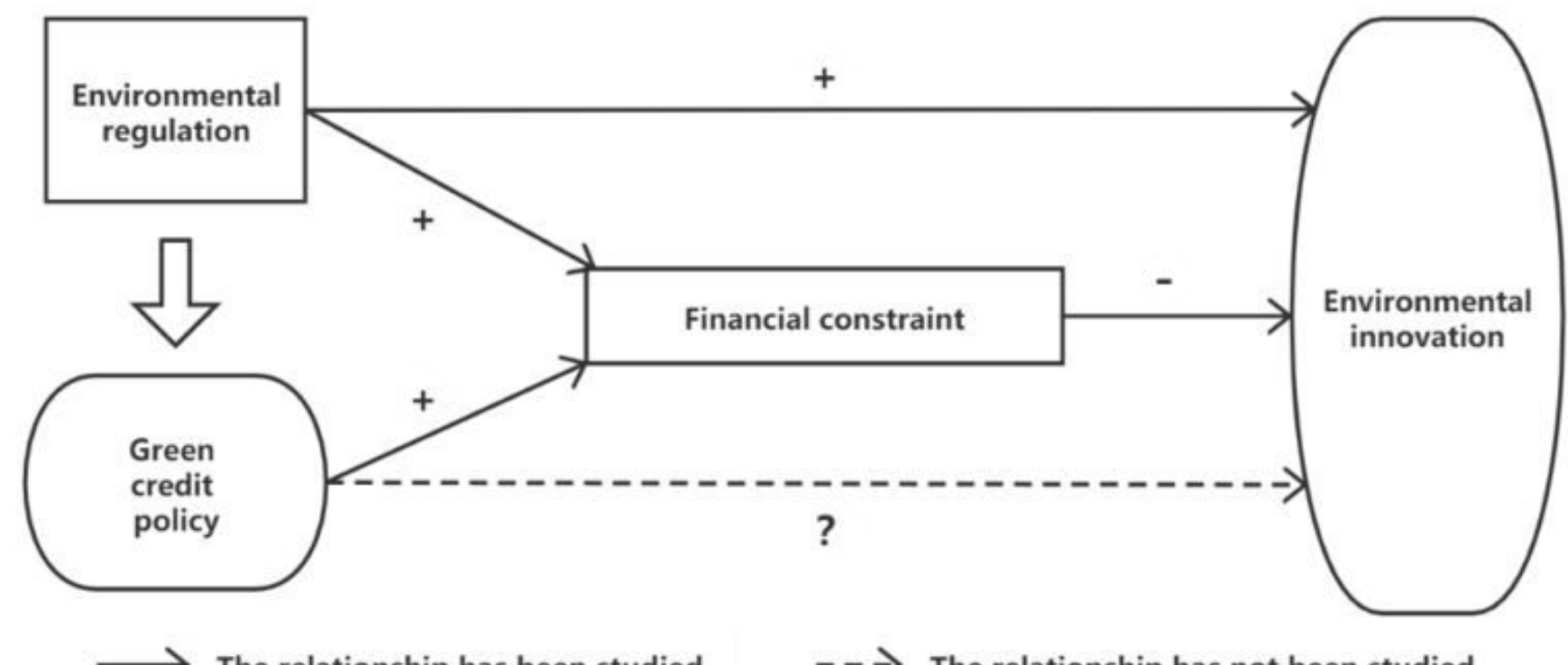

The relationship has been studied. $\quad--\rightarrow$ The relationship has not been studied.

\section{Figure 1}

The logical relationship between the key variables

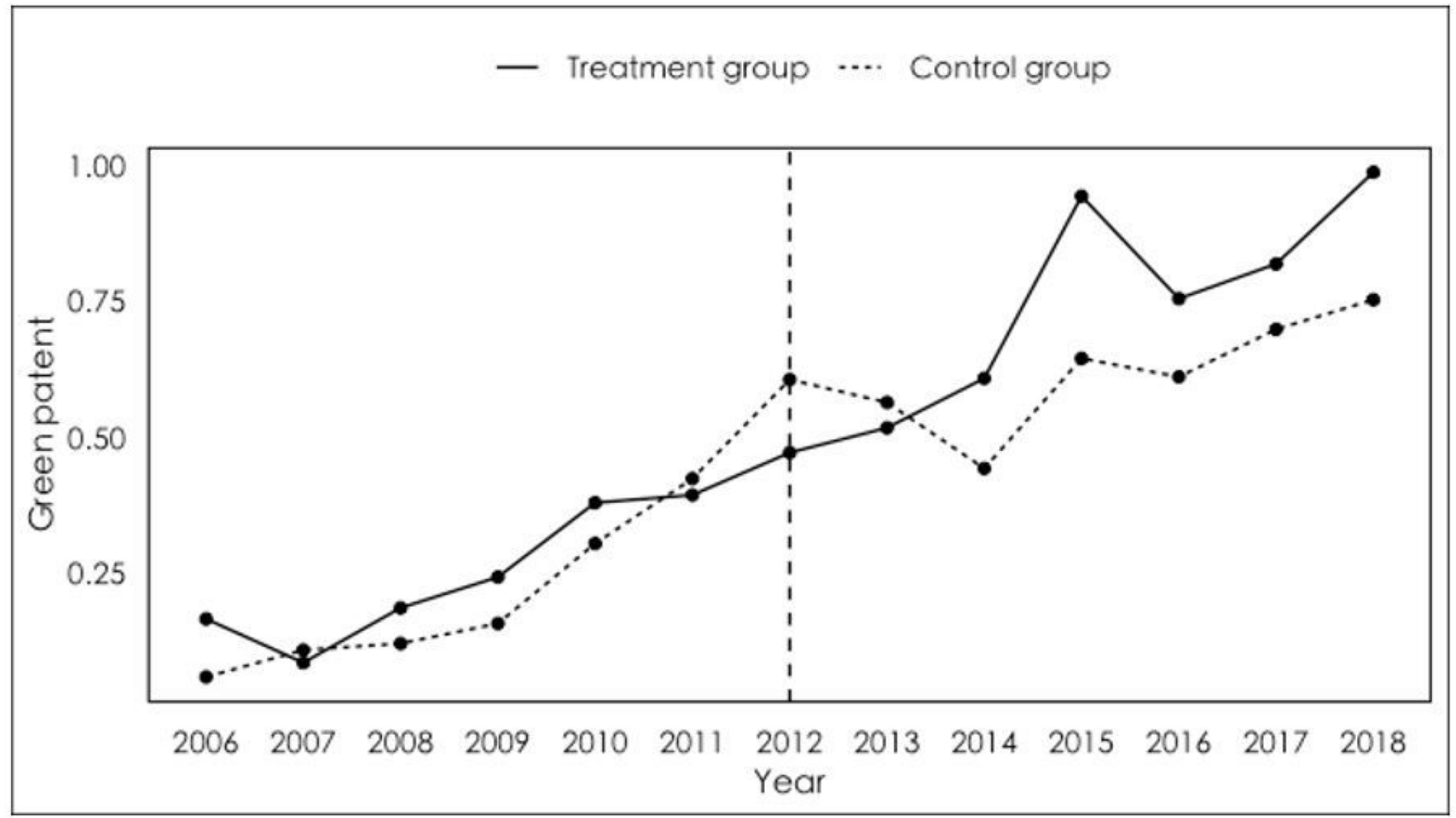

Figure 2 
Dynamic trends of the number of green patents

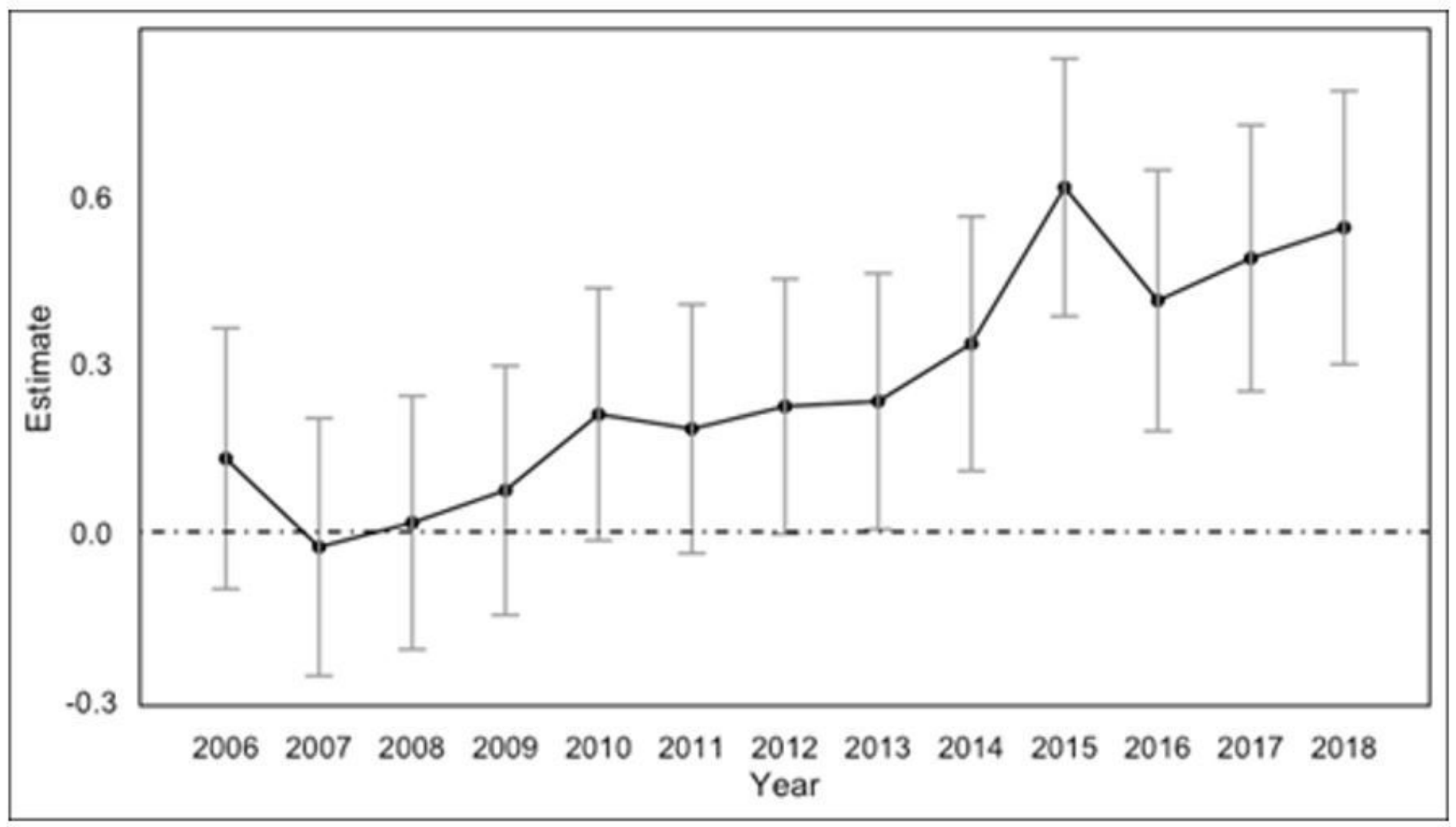

Figure 3

Test of parallel trend

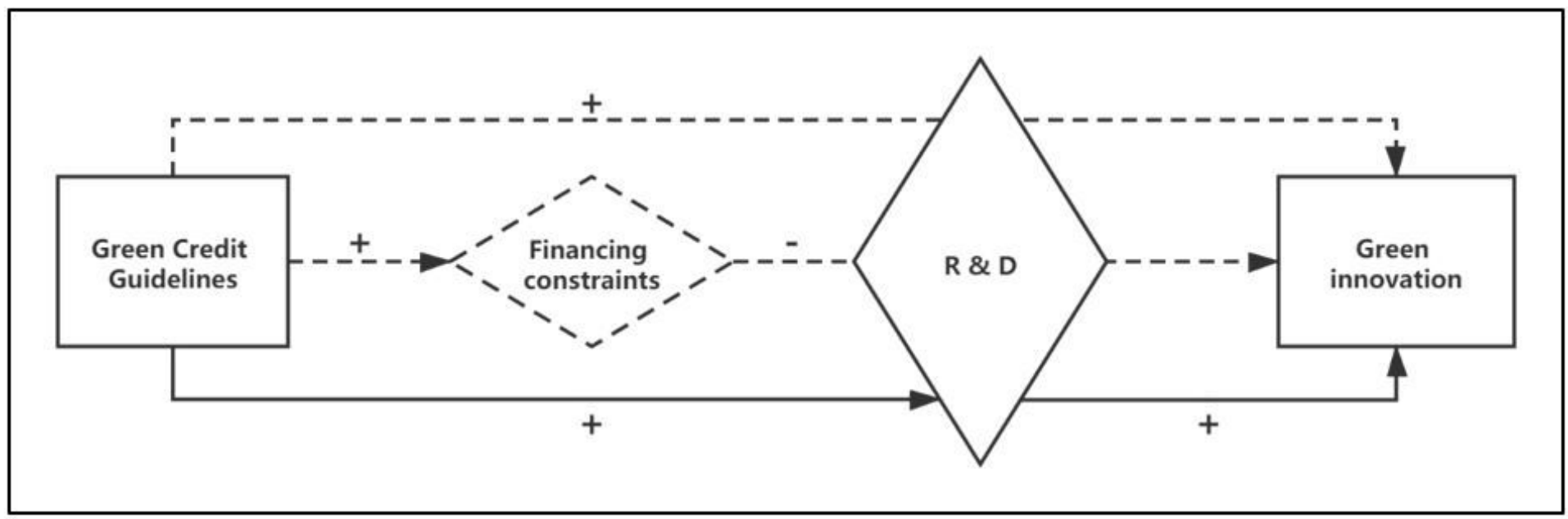

Figure 4

Green Credit Guidelines and Green Innovation: Mechanism path2 